\title{
Pulmonary Vein Leiomyosarcoma
}

National Cancer Institute

\section{Source}

National Cancer Institute. Pulmonary Vein Leiomyosarcoma. NCI Thesaurus. Code C5374.

An aggressive malignant smooth muscle neoplasm, arising from the pulmonary vein. It is characterized by a proliferation of neoplastic spindle cells. 